\title{
Fiddler crab (Crustacea: Ocypodidae) distribution and the relationship between habitat occupancy and mouth appendages
}

\section{Helio Herminio Checon \& Tânia Marcia Costa}

To cite this article: Helio Herminio Checon \& Tânia Marcia Costa (2017) Fiddler crab (Crustacea: Ocypodidae) distribution and the relationship between habitat occupancy and mouth appendages, Marine Biology Research, 13:6, 618-629, DOI: 10.1080/17451000.2016.1273530

To link to this article: https://doi.org/10.1080/17451000.2016.1273530

曲 Published online: 25 Feb 2017.

Submit your article to this journal $\pi$

Џ Article views: 171

View Crossmark data $\complement$

Citing articles: 2 View citing articles 5 


\title{
Fiddler crab (Crustacea: Ocypodidae) distribution and the relationship between habitat occupancy and mouth appendages
}

\author{
Helio Herminio Checon ${ }^{a}$ and Tânia Marcia Costa ${ }^{b}$ \\ ${ }^{\mathrm{a}}$ Graduate Program in Ecology, Department of Animal Biology, State University of Campinas - SP, Brazil; ${ }^{\mathrm{b}}$ Laboratory of Ecology and Animal \\ Behavior, UNESP - São Paulo State University, Bioscience Institute, São Vicente, SP, Brazil
}

\begin{abstract}
Sediment characteristics, especially grain size, are usually considered the most important variables affecting Uca distribution, mainly due to its close relationship with mouth appendage morphology. The aim of this study was to verify, from an assemblage perspective, if sediment is the most important variable affecting Uca species distribution, and if mouth appendage morphology (setae type and curvature) would be related to habitat occupancy. Niche metrics and null model approaches were used to assess and test the hypothesis. The relevance of spoon-tipped setae curvature to Uca distribution was verified for the first time. A fragmented mangrove area was divided into seven subareas, and sampling of crabs and environmental variables took place in June and November 2010. Of 10 species recorded for Brazil, seven were found in the study area: $U$. burgersi, $U$. cumulanta, $U$. leptodactyla, U. maracoani, U. rapax, $U$. thayeri and $U$. uruguayensis. Multivariate analysis showed that sediment grain size and the presence of vegetation were the most important variables explaining distribution, reinforcing results commonly obtained by univariate approaches. The overlap of habitat occupancy was generally low and no relationship between mouth appendages was found with breadth and overlap measures. Contrary to predictions, most non-random overlap values were lower than expected by chance, suggesting that interspecific competition might influence species distribution. Also, variables such as the presence of vegetation are important and influence crab distribution, limiting the potential distribution that would be predicted by mouth adaptations alone. Thus, the use of these adaptations as surrogates of fiddler crab distribution is not recommended.
\end{abstract}

\section{ARTICLE HISTORY}

Received 13 August 2016

Accepted 28 October 2016

Published online 25 February 2017

\section{RESPONSIBLE EDITOR}

Dan Smale

\section{KEYWORDS}

Uca spp. niche breadth; mangrove fauna; niche overlap

\section{Introduction}

Among taxa living on the mangrove substrate, crabs of the genus Uca Leach, 1814, commonly referred to as fiddler crabs, are one of the most widely studied, due to their abundance and peculiar features (Crane 1975; Thurman et al. 2013). The distribution of these organisms is influenced by different variables, such as tide, organic matter content, salinity and shading (Ono 1965; Crane 1975; Thurman et al. 2013; Vermeiren \& Sheaves 2014). However, studies regarding these organisms are often focused on populations or at the species level, and community or assemblage studies are relatively scarce. The occurrence and distribution of fiddler crabs are linked to an array of abiotic and biotic variables. However, sediment characteristics, especially grain size, are considered the most important. This relationship arises from the fiddler crab's dependence on the sediment, both because they feed and extract microorganisms, detritus and benthic macroalgae from the sediment grains, as well as digging burrows within the sediment (Robertson \& Newell 1982; Currin et al. 1995; Ribeiro \& Iribarne 2011).

The dependence of sediment grain size on the feeding process comes from the relationship between grain size and the morphology of mouth appendages. Feeding starts with the manipulation of sediment particles, from which organic matter is extracted by modified setae located on the maxillipeds (Miller 1961; Crane 1975). Based on the ability to extract organic matter, spoon-tipped setae are more suited to coarser sands, while plumose setae are favoured for fine sands and muddy sediments (Robertson \& Newell 1982; Costa \& Negreiros-Fransozo 2001; Lim 2004; Colpo \& Negreiros-Fransozo 2011; Lim \& Kalpana 2011). The simultaneous occurrence of both setal types is common, but Uca species differ in regards to the relative abundance of each type. Recently, spoontipped setae were investigated in regard to their

CONTACT Tânia Marcia Costa $\otimes$ costatm@clp.unesp.br @ Praça Infante Dom Henrique, S/N, Caixa Postal 73610, Parque Bitarú,11380-972, São Vicente, SP, Brazil

(c) 2017 Informa UK Limited, trading as Taylor \& Francis Group 
degree of curvature, and it was suggested that this may also influence fiddler crab distribution, although the extent is yet to be unveiled (Colpo \& Negreiros-Fransozo 2013).

Fiddler crabs are often considered as ecosystem engineers due to the influence of burrow structures on sediment oxygenation and biochemistry (Kristensen 2008). Given the importance of these organisms to mangroves, studies on the ecological characteristics of this assemblage and its components are relevant to the comprehension of faunal dynamics and structure. This study aimed to understand some of these characteristics. Our first hypothesis is that mean grain diameter would be an important variable structuring Uca communities, due to the aforementioned relationship with mouth appendage morphology. We investigated the importance of environmental variables, such as sediment and water characteristics and the presence of vegetation, to assemblage structure. Although other studies tried to establish these relationships, they are often made with univariate analysis approaches, evaluating relationships individually for each species (e.g. correlation, association) (Costa \& Negreiros-Fransozo 2001; César et al. 2005; Bezerra et al. 2006). Here, we offer a multivariate approach to analyse these relationships, which was only recently applied in assemblage studies with Uca species (Mokhtari et al. 2015).

Another hypothesis is that the relationship between sediment and mouth appendage morphology would reflect habitat occupancy patterns. We used a nichebased approach, which to our knowledge is novel in Uca studies and can provide a different view of the importance of mouth appendage morphology to evaluate whether species with similar mouth appendages (setal type and curvature) would exhibit a higher overlap of habitat occupancy due to similar affinities with the sediment. Also, whether species that have both spoon-tipped and plumose setae (mixed type) would have a higher breadth of habitat occupancy due to their capacity for extracting organic matter from different types of sediment.

\section{Materials and methods}

\section{Study area}

This study was carried out in a fragmented mangrove area located in the estuarine system of 'Mar Pequeno' $\left(23^{\circ} 59^{\prime} \mathrm{S} ; 46^{\circ} 24^{\prime} \mathrm{W}\right)$, on the southern coast of the state of São Paulo, Brazil. The mangrove area is known as 'Manguezal do Portinho', and is composed of isolated mangrove fragments with distinct features in regards to sediment, brackish water input and presence of vegetation (Figure 1). The area is used by the local population for entertainment purposes, mainly fishing and rowing activities. Mangrove fragments are mainly composed of Avicennia schaueriana Stapf \& Leechman ex Moldenke, with a few hibiscus species close to the transition to dry land. Brackish water input occurs due to the occurrence of a small stream in the area. No previous studies evaluated the macrofauna in the area, although two other studies were carried out on the ecology of Uca thayeri Rathbun, 1900 (Gusmão-Júnior et al. 2012) and the burrow morphology of fiddler crabs (Machado et al. 2013).

\section{Sampling design}

To characterize different habitats, areas with distinct structural features were selected. These distinct characteristics provide variability of microhabitats, an important and desirable feature to test species distribution in regards to environmental variables and habitat occupation. We aimed to sample areas where no direct and constant human impact was detected, in order to avoid the interference of exogenous variables. Those areas were then divided into subareas according to visual cues of distinct morphological features (Table I).

We applied a stratified random sampling design. This method consists of dividing populations into strata that represent clearly defined groups (e.g. different habitat types) and the sample at each stratum being proportional to its area (Quinn \& Keough 2002). Thus, each subarea was considered as a stratum, with unique conditions. For each subarea, the number of replicates was equal to $10 \%$ of the area $\left(\mathrm{m}^{2}\right)$ (Table I).

Two sampling periods were used, in July and November 2010. Crabs were sampled using quadrats of $1 \times 1 \mathrm{~m}$ as sampling units. Due to the variety of species sizes that could be found, we chose $1 \mathrm{~m}^{2}$ quadrats to ensure that large-sized species would not be undersampled, and to easily estimate the number of replicates required for the stratified sampling. In each quadrat, crabs were carefully taken out of their burrows with the use of a modified hand shovel, sexed and identified to species level. Identification was performed in situ, and crabs were returned to the original area after all sampling to avoid recapture.

\section{Environmental variables}

All subareas were evaluated with regards to the following environmental variables: salinity, $\mathrm{pH}$, mean grain diameter, sorting coefficient, soil moisture content, 


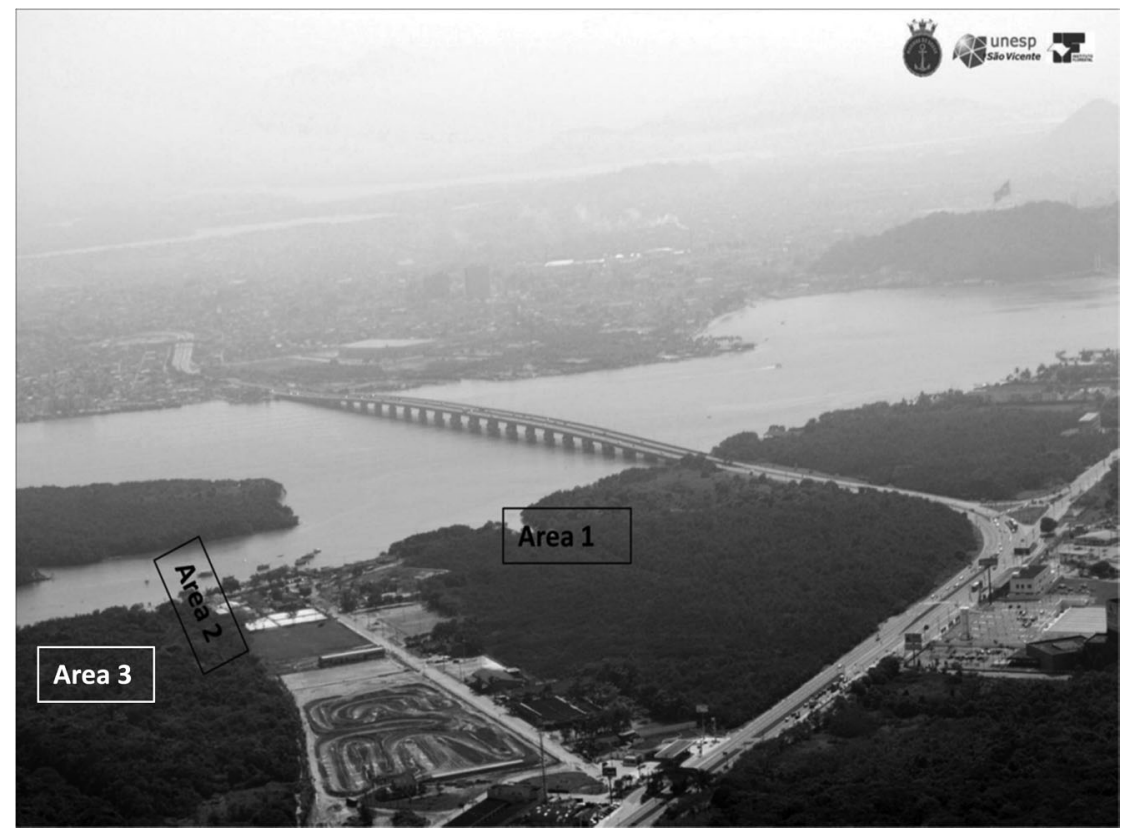

Figure 1. Aerial view of the study area and its surroundings. The location of each area is highlighted.

Table I. Sampling design with area characteristics and subarea division.

\begin{tabular}{|c|c|c|c|c|}
\hline Area & Characteristics & Subareas & Visual cues for subarea distinction & Replicates \\
\hline \multirow[t]{3}{*}{$1\left(60 \mathrm{~m}^{2}\right)$} & River margin & $1 \mathrm{~A}\left(20 \mathrm{~m}^{2}\right)$ & Sandy sediment & 4 \\
\hline & & 1B $\left(20 \mathrm{~m}^{2}\right)$ & Sandy-muddy sediments & 4 \\
\hline & & $1 C\left(20 \mathrm{~m}^{2}\right)$ & Muddy sediments & 4 \\
\hline \multirow[t]{2}{*}{$2\left(140 \mathrm{~m}^{2}\right)$} & Small stream & $2 \mathrm{~A}\left(70 \mathrm{~m}^{2}\right)$ & Close to stream mouth, no vegetation and low water volume & 14 \\
\hline & & $2 B\left(70 \mathrm{~m}^{2}\right)$ & Distant from stream mouth, vegetation presence and higher water volume & 14 \\
\hline \multirow[t]{2}{*}{$3\left(360 \mathrm{~m}^{2}\right)$} & Mangrove forest & $3 A\left(220 \mathrm{~m}^{2}\right)$ & $\begin{array}{l}\text { Low intertidal mangrove, higher tide influence, under vegetation, muddy } \\
\text { sediments }\end{array}$ & 44 \\
\hline & & $3 B\left(140 \mathrm{~m}^{2}\right)$ & $\begin{array}{l}\text { Upper intertidal mangrove, not covered by tide, under vegetation, sandy } \\
\text { sediments }\end{array}$ & 28 \\
\hline
\end{tabular}

Notes: The number of replicates is also shown $\left(10 \%\right.$ of each subarea size $\left.\left(\mathrm{m}^{2}\right)\right)$. Number of replicates refers to both sampling periods.

organic matter and presence of vegetation (presence/ absence). We chose these variables as they are commonly related to Uca distribution (Robertson \& Newell 1982; Bezerra et al. 2006; Thurman et al. 2013; Mokhtari et al. 2015). To analyse these variables, five sediment and water samples were randomly collected in each subarea after crab sampling, on the same day to reduce the effects of daily variations (e.g. rains or wind surges). Samples at each subarea were collected simultaneously to avoid differences caused by the tidal variations, especially for soil moisture contents. Sediment samples were collected as a $10 \mathrm{~cm}$ deep profile, with the use of a metal spoon. Water samples were collected during low spring tides and preserved in sterile glass pots inside an insulated cooler.

Soil moisture content was quantified by drying sediment fractions in an oven at $60^{\circ} \mathrm{C}$ for 72 hours. Organic matter content was evaluated using the resulting dried samples, which were burned in a muffle furnace at $500^{\circ} \mathrm{C}$ for 3 hours. For both variables, the value calculated was the difference between initial and final weight after each specific process. To evaluate the pattern of sedimentological texture, the Wentworth scale was adopted (Wentworth 1922). The mean grain diameter was calculated according to McCammon (1962), and given in a phi $(\phi)$ scale.

Hydrological parameters ( $\mathrm{pH}$ and salinity) were evaluated by taking samples from the closest body of water at each subarea. This procedure was chosen because some subareas did not present enough pore water at the burrow's depth. Because all areas were close to the tide line, the closest body of water was no farther than 2-3 $\mathrm{m}$. We believe this distance will allow the sample from the body of water to be a good proxy of the pore water. Areas 1 and 3 have the same values for all subareas, as they were under the influence of the same water source. For Area 2, an analysis was performed due to the considerable difference in distances of each subarea from the tide range, which could affect salinity measurement. Salinity was evaluated with a 
manual refractometer, whereas $\mathrm{pH}$ was evaluated with a pH meter. Vegetation cover was considered as a categorical variable, and only presence or absence was registered. Tree height was not included as it had little variability between subareas.

\section{Data analysis}

Differences in environmental variables among the subareas were evaluated using linear mixed models (LMM). Normal distribution was checked by observing variations in probability plots, whereas variance homogeneity was checked by Bartlett's test (Quinn \& Keough 2002). Data that violated linear model assumptions were log-transformed before fitting the model (Quinn $\&$ Keough 2002). Because we were not interested in temporal variations, sampling periods were considered as random factors in the model and subareas as fixed factors. Due to the stratified sampling design, sampling efforts at each subarea were different, and thus mean densities were calculated separately for each subarea, accounting for the sample variation (Quinn \& Keough 2002). These mean values were used in further analyses.

The relationship between species distributions and environmental variables was assessed by means of a redundancy analysis (RDA). Given the influence that null values have on estimating Euclidean distance, density data were transformed by the Hellinger function (Legendre \& Gallagher 2001). The variance inflation factor (Vif) was calculated to identify multivariate collinearity, considering Vifs $>10$ as limit values for strong collinearity, and Spearman correlation was calculated to identify pairwise collinearity. If strong collinearity was detected, the variable with highest Vif was excluded from the analysis in order to alleviate distortions caused by this issue, and the model checked again for collinearity. The significance of axes and variables was evaluated by ANOVA, with permutation tests. The selection of variables that best explained the variation of species distribution was made by the method of double-stopping criteria, which reduces the likelihood of retaining less-important variables (Blanchet et al. 2008), and a new ordination was generated using only the selected variables.

Niche metrics are relevant to understand how a given community may respond to habitat changes and the potential interactions between species (Pianka 1973; Swihart et al. 2003). To calculate these metrics, each subarea was considered as a different resource (habitat), and niche metrics were calculated based on the proportion of occupancy of each species at each area. Breadth was calculated using Levins Standardized Index ( $\mathrm{Ba})$, which is based on mean abundance at each resource and how many different resources each species occupies. The index ranges from 0 (minimum breadth, only one resource) to 1 (maximum breadth, proportional presence on all resources) (Krebs 1989). Overlap of habitat occupancy was assessed using the Pianka overlap index (Pianka 1973). This index is calculated for each species pair, based on the shared proportional occupation of all resources (derived from standardized densities), ranging from 0 (no overlap; share no resource at all) to 1 (total overlap; share exclusively the same resource).

Null-models were employed to estimate overlap values for each observed value obtained, using the algorithm RA2 with Monte Carlo permutations ( $n=$ 30,000). This algorithm randomizes retaining zero values (i.e. if a species does not occupy a particular resource, then it will not in the randomized assemblage either), and replacing non-zero values with random numbers (0-1) (Gotelli \& Graves 1996). If mouth appendage morphology truly constrains Uca distribution, the overlap values for species pairs with similar appendages and assemblage would be higher than expected by chance $\left(P_{\text {obs }>\text { exp }}<0.05\right)$. Null models were run for each species pair and for the whole assemblage. Also, when a category of setal type and/or curvature had more than two species, null-models were also used to evaluate non-randomness on overlap patterns among these species.

The morphology of mouth appendages was verified in specialized literature for the species found at the study area (Costa \& Negreiros-Fransozo 2001; Bezerra et al. 2006; Colpo \& Negreiros-Fransozo 2011; Thurman et al. 2013). We checked different studies in order to avoid intraspecific variations from different locations. Both setal type and spoon-tipped setae curvature were classified. Setal type was classified as (a) plumose, (b) spoon-tipped or (c) mixed, whereas curvature was assigned as (a) slight, (b) moderate or (c) highly concave. Although one species may possess multiple setal types (Yamaguchi \& Ogata 2000), classification is based on the most abundant type. Thus, curvature of spoon-tipped setae can be assigned to species with dominance of plumose setae. The mixed category may also be considered too broad, but we believe that evaluating this category is relevant given the application of the mixed category in studies with Uca (Costa \& Negreiros-Fransozo 2001; Bezerra et al. 2006; Thurman et al. 2013). Morphology was qualitatively compared with breadth and overlap results for each pair of species, coupled with null-model results, to test our initial hypothesis. 


\section{Results}

\section{Environment and assemblage characterization}

Normal distribution assumption was violated by salinity data, whereas variance heterogeneity was found for soil moisture content (Bartlett test, $K^{2} \sigma=25.146$, $P<0.001$ ), organic matter (Bartlett test, $K^{2} \sigma=33.668$, $P<0.001$ ) and mean diameter (Bartlett test, $K^{2} \sigma=$ $17.302, P=0.008)$. Thus, these variables were log-transformed to better fit the assumptions. We also excluded the maximum and minimum values of the variable data due to the presence of outliers or aberrant values.

Differences among subareas were found for organic matter $(\mathrm{LMM}, F(6,28)=20.283, P<0.001)$, mean diameter of sediment grains $(\operatorname{LMM}, F(6,28)=18.387, P=$ $0.001)$ and soil moisture content (LMM, $F(6,28)=$ 49.138, $P<0.001)$. Subarea $3-A$ sediment had finer grains and presented a higher organic matter and soil moisture content (Figure 2). Mean sorting values for subareas varied from poorly to moderately sorted, but no differences were found between subareas in the model $(\mathrm{LMM}, F(6,28)=3.092, P=0.097)$. In relation to water-related variables, no differences among subareas were found both for $\mathrm{pH}$ values (LMM, $F(3,16)=$ $6.175, P=0.084)$ and salinity $(\operatorname{LMM}, F(3,16)=1.689, P$ $=0.339$ ). Subareas $1-A$ and $1-B$ were located in the same area and no differences between them were found for any of the environmental variables evaluated. Thus, they were grouped for diversity and niche metrics calculation, since we had no evidence to consider them as different resources.

A total of 983 crabs belonging to genus Uca were sampled. Seven species were found: Uca (Minuca) burgersi Holthius, 1967, Uca (Leptuca) cumulanta Crane, 1943, Uca (Leptuca) leptodactyla Rathbun, 1898, Uca (Uca) maracoani (Latreille, 1802), Uca (Minuca) rapax (Smith, 1870), Uca (Minuca) thayeri and Uca (Leptuca) uruguayensis Nobili, 1901. The most abundant species were $U$. thayeri and $U$. uruguayensis, considering total number of individuals sampled, due to their presence in the largest subareas (mangrove forest, area 3). However, when mean density is considered, $U$. leptodactyla, $U$. thayeri and $U$. uruguayensis were the most prevalent. The dominant species in terms of density was different at each subarea in at least one of the sampling periods: $U$. leptodactyla in subarea $1-A\left(17.5 \mathrm{ind} / \mathrm{m}^{2}\right) ; U$. rapax and $U$. burgesi in subarea 2-B (2.28 and $3.71 \mathrm{ind} / \mathrm{m}^{2}$, respectively); and $U$. thayeri in subareas $1-B\left(3.5 \mathrm{ind} / \mathrm{m}^{2}\right), 3-A\left(9.71 \mathrm{ind} / \mathrm{m}^{2}\right)$ and $3-B$ $\left(6.04 \mathrm{ind} / \mathrm{m}^{2}\right)$. Uca uruguayensis were found with more consistent mean densities, with $>4 \mathrm{ind} / \mathrm{m}^{2}$ in all subareas, except 1-C and 3-A. Uca cumulanta and
$U$. maracoani were the least abundant species, with the latter found mainly in subarea 1-C (Table II).

Redundancy analysis was carried out separately with two models: one with all environmental variables, and another only with variables selected by the doublestopping criteria. The variable selection model indicated mean grain diameter $\left(\mathrm{FS}, R^{2}=0.223, F=3.455\right.$, $P=0.007)$ and presence of vegetation (FS, $R^{2}=0.139$; $F=2.389, P=0.04$ ) as those that best explained variations in species distribution. The first model, with all variables, explained $62.4 \%$ of the variation in species distribution (RDA, $F(6,7)=1.939, P=0.022)$, whereas the second model, with selected variables, explained $36.2 \%$ of variation in species distribution (RDA, $F(2,11)=3.855, P=$ 0.005) (Table III). Uca burgersi, $U$. rapax and $U$. uruguayensis were associated with presence of vegetation, whereas the opposite was observed for $U$. maracoani. Uca thayeri was associated with areas with finer sediment grains, while $U$. leptodactyla was found in areas with coarser sands (Figure 3). The density of $U$. cumulanta was too low to infer any relationships.

The sorting coefficient was the variable with highest variance inflation factor (12.87), above the limit value of 10 for strong collinearity. We opted to exclude this variable in order to lower Vif values for other variables and alleviate collinearity. This way, variance inflation factor was high for organic matter, soil moisture content and mean grain diameter $(8.056,7.457$ and 6.938, respectively), and low for the other variables $(\mathrm{pH}: 1.645$, salinity: 1.642, vegetation: 2.308 ), but were all below the limit value. The pairwise Spearman correlation matrix was calculated among continuous variables, which registered high correlation values for sedimentrelated variables, especially for sorting with mean diameter (Spearman rank correlation, $\mathrm{rs}=-0.81, N=$ 14) and for soil moisture content with organic matter (Spearman rank correlation, $r s=0.79, N=14$ ) and mean diameter (Spearman rank correlation, $r s=0.67$, $N=14)$.

\section{Mouth appendages and habitat occupancy}

All variations of setal type and setal curvature were found among the species sampled. The morphology was consistent throughout the literature, reducing the risk of intraspecific variations. Uca leptodactyla was the only species classified as having primarily spoon-tipped setae. In contrast, U. maracoani and $U$. thayeri were classified as having a dominance of plumose setae. The other species were classified as mixed types. Curvature of spoon-tipped setae was classified as slight for $U$. burgersi and $U$. thayeri; 

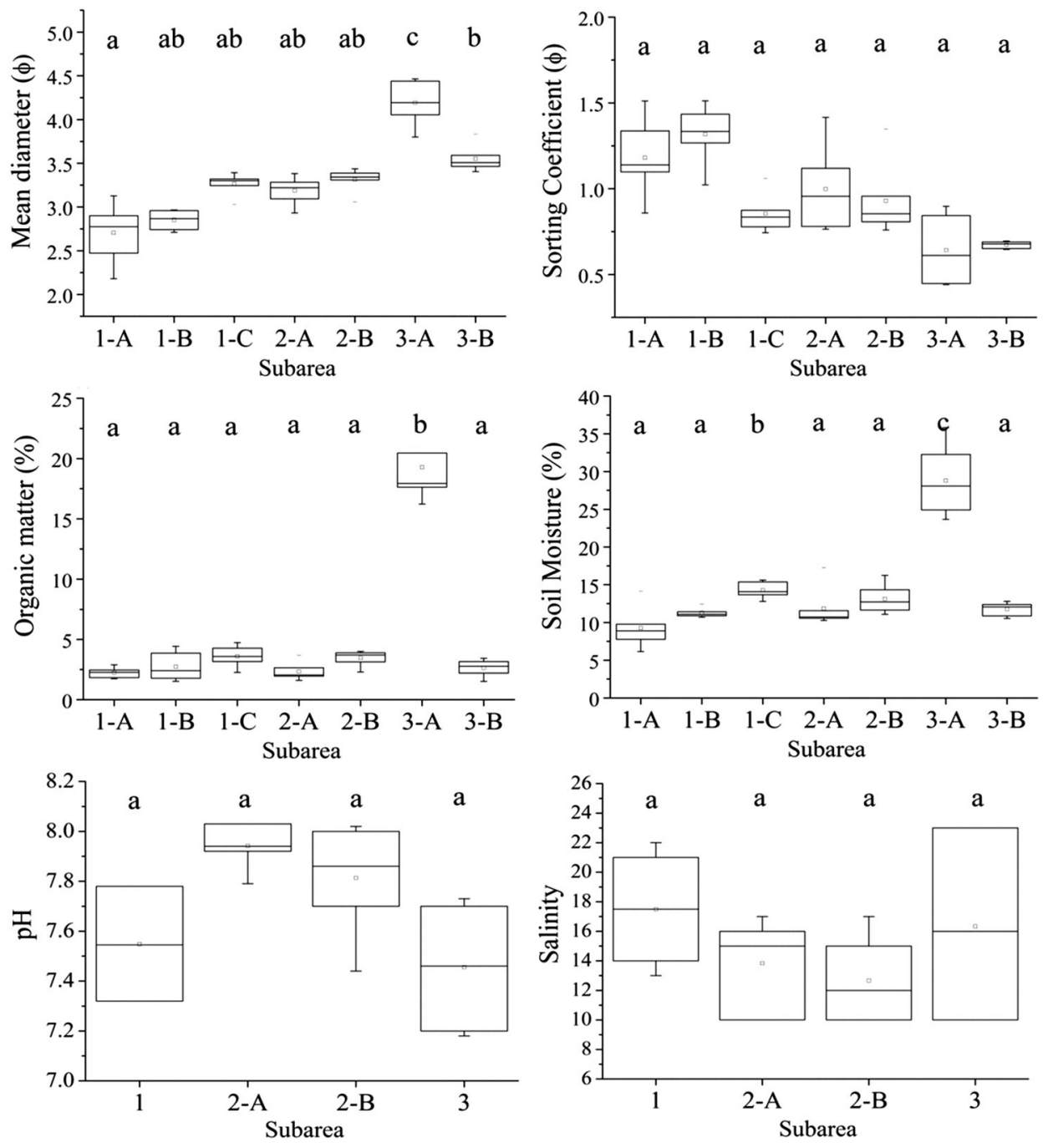

Figure 2. Box-and-whiskers plot for the environmental parameters for each subarea at 'Manguezal do Portinho'. The horizontal line within the box indicates the median value, boundaries of the box indicate the 25th and 75th percentile, and the whiskers indicate the $95 \% \mathrm{Cl}$. The white dots indicate the mean values. Different letters indicate statistical significance of linear mixed model analysis $(p<0.05)$. Organic matter and soil moisture content are given as percentages and mean diameter is represented in phi scale $(\phi)$.

Table II. Mean densities of Uca species (individuals $/ \mathrm{m}^{2}$ ) for the sampling subareas at 'Manguezal do Portinho'.

\begin{tabular}{|c|c|c|c|c|c|c|c|c|}
\hline \multirow[b]{2}{*}{ Species } & \multirow[b]{2}{*}{ Month } & \multicolumn{7}{|c|}{ Subarea } \\
\hline & & $1-\mathrm{A}$ & $1-B$ & $1-C$ & $2-\mathrm{A}$ & $2-B$ & $3-\mathrm{A}$ & $3-B$ \\
\hline \multirow{2}{*}{ U. burgersi Holthuis, 1967} & July & 0 & 0 & 0 & 0 & 1.43 & 0 & 0 \\
\hline & Nov & 0 & 0 & 0 & 0 & 3.71 & 0.04 & 0 \\
\hline \multirow{2}{*}{ U. cumulanta Crane, 1943} & July & 0 & 0 & 0 & 0 & 0 & 0 & 0.14 \\
\hline & Nov & 0 & 0 & 0 & 0 & 0 & 0 & 0 \\
\hline \multirow[t]{2}{*}{ U. leptodactyla Rathbun, 1898} & July & 6 & 0.5 & 0 & 0.28 & 0 & 0 & 0 \\
\hline & Nov & 17.5 & 5 & 0 & 0.74 & 0 & 0 & 0.07 \\
\hline \multirow[t]{2}{*}{ U. maracoani (Latreille, 1802) } & July & 0 & 0 & 1.5 & 0 & 0 & 0 & 0 \\
\hline & Nov & 0 & 1.5 & 1.5 & 0 & 0 & 0 & 0 \\
\hline \multirow[t]{2}{*}{ U. rapax (Smith, 1870) } & July & 0 & 0 & 0 & 0 & 2.14 & 0 & 0 \\
\hline & Nov & 0 & 0 & 0 & 0 & 2.28 & 0 & 0 \\
\hline \multirow[t]{2}{*}{ U. thayeri Rathbun, 1900} & July & 0 & 3 & 0 & 2.28 & 2 & 4.14 & 9.71 \\
\hline & Nov & 0 & 3.5 & 2 & 2 & 2 & 6.04 & 4 \\
\hline \multirow[t]{2}{*}{ U. uruguayensis Nobili, 1901} & July & 0 & 2.5 & 0 & 4.43 & 0.71 & 0 & 8.5 \\
\hline & Nov & 4.5 & 5 & 0 & 5.57 & 5.29 & 0.23 & 7.07 \\
\hline
\end{tabular}


Table III. Summary of redundancy analysis results for the model with all variables included, and the model with only selected variables.

\begin{tabular}{|c|c|c|c|c|c|}
\hline \multicolumn{3}{|c|}{ RDA (All) } & \multicolumn{3}{|c|}{ RDA (Selected) } \\
\hline & Inertia & Proportion & & Inertia & Proportion \\
\hline Constrained & 0.323 & 0.624 & Constrained & 0.187 & 0.362 \\
\hline Unconstrained & 0.194 & 0.375 & Unconstrained & 0.330 & 0.638 \\
\hline Model & $F_{(6,7)}=1.939 P=0.0$ & & Model & $F_{(2,11)}=3.122 P=0$ & \\
\hline \multirow[t]{2}{*}{$R^{2}$ adjusted } & & & $R^{2}$ adjusted & & \\
\hline & RDA 1 & RDA 2 & & RDA 1 & RDA 2 \\
\hline Proportion explained & 0.289 & 0.232 & Proportion explained & 0.22 & 0.14 \\
\hline \multirow[t]{2}{*}{ ANOVA $($ perm $=199)$} & $F=5.377 P=0.005$ & $F=4.330 P=0.02$ & ANOVA (perm = 199) & $F=3.861 P=0.01$ & $F=2.382 P=0.03$ \\
\hline & $F$ test perm $=999$ & $p$ value & & $F$ test perm $=999$ & $p$ value \\
\hline Organic matter & 2.735 & 0.09 & Mean diameter & 3.855 & 0.02 \\
\hline Mean diameter & 3.084 & 0.04 & Vegetation & 2.388 & 0.04 \\
\hline Soil moisture content & 1.149 & 0.06 & & & \\
\hline $\mathrm{pH}$ & 0.513 & 0.84 & & & \\
\hline Vegetation & 2.067 & 0.05 & & & \\
\hline
\end{tabular}

Note: Bold indicates statistical significance of permutation method.

moderate for $U$. rapax and $U$. cumulanta; and highly concave for $U$. leptodactyla, $U$. maracoani and $U$. uruguayensis (Table IV).

Uca thayeri and $U$. uruguayensis were the only species that showed high breadth values, occupying different areas with more even mean densities. The other species had low breadths, occupying two or three subareas ( $U$. leptodactyla, $U$. burgersi and $U$. maracoani), or had null values, occurring in only one subarea ( $U$. cumulanta and $U$. rapax). The low breadth values reflected the lack or low overlap

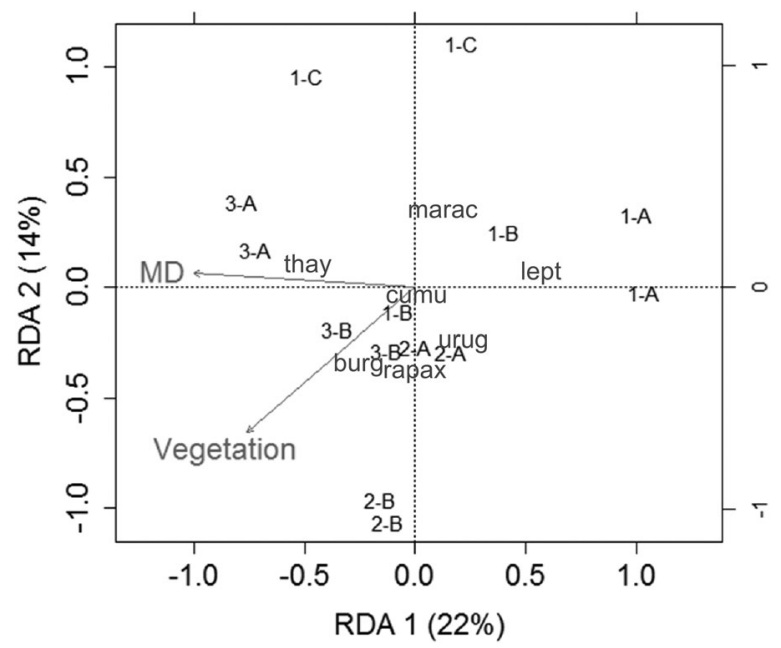

Figure 3. Ordination triplot of the redundancy analysis for model with the selected variables. Site, species and variable scores are plotted. The first axis stands for the variation related mainly to mean diameter (MD), while the second axis for the variation is related to the presence/absence of vegetation. Species are coded as shortened names as follows: burg, Uca burgersi; cumu, U. cumulanta; lept, U. leptodactyla; marac, U. maracoani; rapax, U. rapax; thay, U. thayeri; urug, $U$. uruguayensis. found for many species pairs. Uca burgersi and $U$. rapax had maximum overlap, co-occurring in subarea 2-B and high overlap was also found for $U$. thayeri and $U$. uruguayensis (Table IV).

Breadth did not seem to be related to the presence of mixed-type setae. Uca thayeri (plumose setae) and $U$. uruguayensis (mixed setae) were the species with highest breadths, but other mixed type species (U. rapax and $U$. burgersi) were found almost exclusively in one area.

No clear relationships could be established between overlap values and mouth appendages. Despite some cases like $U$. rapax and $U$. burgersi having maximum overlap and similar setal type composition, species with different setal composition such as $U$. uruguayensis and $U$. thayeri also showed high overlap. Non-randomness was observed among some species pairs and for the whole assemblage result. However, the only overlap higher than expected by chance for species with similar setal configuration was between $U$. burgersi and $U$. rapax (Obs: 1.00; Exp: $\left.0.654 ; P_{\text {obs }>\exp }=0.001\right)$. Other associations of species with mixed-type setae were either lower than expected by chance or randomly structured. Mixed-type assemblages also showed low overlap and random distribution (Obs: 0.360; Exp: 0.431; $P_{\text {obs }<\exp }=0.194$ ).

Overlap between the only species with dominance of plumose setae ( $U$. thayeri and $U$. maracoani) was low and not different from simulated results (Obs: 0.136; Exp: 0.459; $P_{\text {obs <exp }}=0.06$ ), further limiting the establishment of a direct relationship between mouth appendages and species overlap. Uca maracoani also had the highest calculated overlap with $U$. leptodactyla, the only species with spoon-tipped setae, although it was not different 
Table IV. Levin's standardized niche breadth $(\mathrm{Ba})$ and Morisita's overlap index results for Uca species at Mangue do Portinho.

\begin{tabular}{|c|c|c|c|c|c|c|c|c|c|c|}
\hline Species & 2nd maxilliped & Setae curvature & $\mathrm{Ba}$ & U. burg & U. ситu & U. lepto & U. mara & U. rapax & U. thay & U. urug \\
\hline U. burgersi & Mixed & Slight & 0.01 & $\mathrm{X}$ & 0 & 0.01 & 0 & 1.00 & 0.107 & 0.222 \\
\hline U. cumulanta & Mixed & Moderate & 0 & & $\mathrm{x}$ & 0.01 & 0 & 0 & 0.798 & 0.718 \\
\hline U. leptodactyla & Spoon-tipped & Highly concave & 0.03 & & & $\mathrm{X}$ & 0.241 & 0 & 0.198 & 0.305 \\
\hline U. maracoani & Plumose & Highly concave & 0.08 & & & & $\mathrm{X}$ & 0 & 0.136 & 0.057 \\
\hline U. rapax & Mixed & Moderate & 0 & & & & & $\mathrm{X}$ & 0.107 & 0.221 \\
\hline U. thayeri & Plumose & Slight & 0.46 & & & & & & $\mathrm{x}$ & 0.831 \\
\hline \multirow[t]{4}{*}{ U. uruguayensis } & Mixed & Highly concave & 0.38 & & & & & & & $x$ \\
\hline & Mixed-type assembly & & 0.364 & & & & & & & \\
\hline & Highly concave assembly & & 0.201 & & & & & & & \\
\hline & Total overlap & & 0.235 & & & & & & & \\
\hline
\end{tabular}

Bold: $P_{\text {obs }<\exp }<0.05$, Italic: $P_{\text {obs }>\exp }<0.05$.

Notes: Second maxilliped setae type and spoon-tipped setae curvature are added for comparative reasons.

from that expected by chance (Obs: 0.241 ; Exp: 0.325 ; $P_{\text {obs }<\text { exp }}=0.425$ ).

Setal curvature also could not be related to habitat overlap. No overlap was found between species with moderate curvature (U. cumulanta and U. rapax), and a low and non-random overlap was found between species with slight curvature $(U$. burgersi and U. thayeri, Obs: 0.107; Exp: 0.458; $\left.P_{\text {obs }<\exp }=0.037\right)$. Overlap between the three species with highly concave spoon-tipped setae $(U$. leptodactyla, $U$. maracoani and $U$. uruguayensis) was low and random (Obs: 0.201; Exp: 0.398; $P_{\text {obs }<\text { exp }}=0.069$ ). Also, the highest observed overlaps ( $U$. burgersi and $U$. rapax, $U$. uruguayensis and $U$. thayeri) were between species pairs with different spoon-tipped setal curvature (Table IV). A medium overlap value was found for the Uca assemblage, but structure was detected as the observed value was lower than expected by chance (Obs: 0.235; Exp: 0.357; $P_{\text {obs }<\exp }$ $=0.002$ ).

\section{Discussion}

\section{Environment and assemblage characterization}

As hypothesized, the multivariate approach indicated that mean sediment grain diameter was the variable that best explained Uca species distribution. Presence of vegetation was also an important explanatory variable. Of the 10 Uca species found along the Brazilian coast, seven were present in the study area. Their densities and distribution were variable, as some species had high densities and occurred in different subareas (U. uruguayensis and $U$. thayeri), and others had restricted distributions and lower densities (U. maracoani and $U$. cumulanta). Subareas varied greatly with regards to salinity, vegetation and sediment characteristics.

Multivariate approaches are important tools in community ecology studies, allowing for the interpretation of the simultaneous relationships among a set of variables and species distribution, enabling inferences that cannot be made with univariate statistics (James \& McCulloch 1990). Our multivariate approach supports the results obtained by univariate ones that sediment grain size is one of the most important variables for Uca species distribution, as was also recently found by Mokhtari et al. (2015). However, studies with univariate approaches have considered soil moisture, organic matter and $\mathrm{pH}$ to be correlated to a given species distribution (César et al. 2005, Bezerra et al. 2006), but our results did not detect the influence of these variables on structuring Uca assemblages. This highlights the differences between the two approaches and researchers should bear this in mind in order to choose the appropriate method to answer a particular question.

Mean diameter is acknowledged as one of the most important variables affecting Uca distribution (Miller 1961; Thurman 1987; Bezerra et al. 2006; Mokhtari et al. 2015). In fact, some Brazilian species have established clear relationships with sediment type, such as $U$. leptodactyla occurring on coarse sands and U. maracoani on silt/muddy sediments (Costa \& Negreiros-Fransozo 2001; Bezerra et al. 2006; Thurman et al. 2013). However, the interpretation of this relationship may not be straightforward. The mechanism that governs the animal-sediment relationship is hard to establish if we consider sediment as an isolated variable. It is important to consider that this relationship may exhibit indirect associations with sediment-related variables (Gray 1974; Hyland et al. 2005; Thrush et al. 2005). In fact, our results show a significant positive correlation between mean grain diameter with soil moisture content, and strong negative correlation with sorting coefficient. In this case, species occurring in fine sands are related to higher soil moisture content and better sorted sediments, whereas the opposite can be found for fiddler crab species occurring in coarser sands. Soil moisture directly influences sediment temperature and, 
coupled with the sorting coefficient, can influence burrowing activities, as drier and poorer sorted sediments are more likely to be compacted and hinder burrowing (Brenchley 1982). Sediment may also be related to variables not considered or that operate at distinct scales, such as microbial fauna density, dissolved oxygen or local hydrodynamics (Gray 1974; Thrush et al. 2005; Anderson 2008). Thus, the importance of sediment grain size found for Uca species distribution should not be related directly with mouth appendage morphology, as variables correlated with mean diameter may also play a role.

Grain size can also influence the burrowing of fiddler crabs. Finer sediments are more cohesive and may enable the construction of deeper burrows by crabs (Morrissey et al. 1999). Deeper burrows, especially at higher intertidal areas, are likely to lower the temperature stress during low tides (Lim \& Diong 2003). Fiddler crab species also have different burrowing capabilities, resulting in contrasting burrow morphologies with sediment variation (Morrissey et al. 1999; Quresh \& Saher 2012). It is likely these constraints imposed by sediment penetrability may influence habitat choice by fiddler crab species.

The presence of vegetation was another significant variable explaining Uca distribution, especially for $U$. maracoani and $U$. leptodactyla, which were absent in vegetated areas; and $U$. burgersi and $U$. rapax, found only in vegetated areas. The presence of vegetation may exert a negative influence on species by limiting visibility. Nobbs (2003) found that U. (Australuca) elegans George \& D.S. Jones, 1982 avoid plantcovered areas, as this species frequently uses complex visual signals and vegetation would hinder the visibility of these signals. A similar situation may occur with U. maracoani, which uses complex displays and would avoid vegetated areas due to this behaviour (Bezerra et al. 2006). Uca thayeri is known to use both visual and acoustic signals (Crane 1975; Salmon 1987), but the relative importance of the latter is yet to be studied. Also, U. leptodactyla was found in higher densities in unvegetated areas, building hoodtype sedimentary structures on the entrance of burrows, an important visual signal for reproduction (Christy et al. 2002), whereas U. thayeri build chimneytype sedimentary structures, which are suggested to function as a defensive or regulatory mechanism (Gusmão-Júnior et al. 2012). These contrasting uses of sedimentary structures are in accordance with the absence of $U$. leptodactyla under the canopy, and the high density of $U$. thayeri in the mangrove forest. Our results regarding the importance of vegetation may be a reflection of these behavioural responses.
Vegetation cover may exert a positive influence on benthic macrofauna distribution, acting as a source of organic matter, through plant decomposition (Currin et al. 1995) or by lowering desiccation stress caused by direct exposure to sunlight (Nobbs 2003; Kon et al. 2009). A lack of shading may lead to increased salinity and temperature resulting from higher heat input, creating conditions more stressful to the establishment of macrofauna species (Nobbs 2003; Whitcraft \& Levin 2007). Also, changes in microalgal communities are also expected by the lack of shading (e.g. increased diatom domination) and macrofauna dependent on these microalgae as food sources may be affected (Whitcraft \& Levin 2007). These unicellular algae are an important food source for fiddler crabs (Ribeiro \& Iribarne 2011) and are readily available, without the need for microbial activity for assimilation as in the case of plant detritus (Tenore 1983). The presence of pneumatophores can also influence Uca distribution, as these structures alter burrow morphology and can provide burrow stability on muddier sediments, such as those found at subarea 3-A (Bertness \& Miller 1984; Lim \& Rosiah 2007).

\section{Mouth appendages and habitat occupancy}

The morphology of mouth appendages could not be related to habitat occupancy metrics. The hypothesis that there is overlap among species with similar mouth appendage morphology was refuted, due to the general low overlap, but also to the high overlap found between species with contrasting setal types. Monte Carlo simulations revealed no trend of observed overlaps higher than expected by chance for assemblages and species pairs of the same setal type. Also, species with mixed-type setae did not present higher breadth, as previously hypothesized. Species with high habitat breadth (Uca thayeri and $U$. uruguayensis) had different setal types. Thus, niche metrics could not be directly related to mouth appendage morphology.

Non-randomness among species pair was detected only for associations with $U$. burgersi and $U$. cumulanta. These results were likely due to the low densities displayed by these species at one of the subareas, implying that their occupation of these resources may be restricted by some process. Uca cumulanta is a species that occurs at a low density throughout the Brazilian coast, especially in the southern region, and may represent a species at the edge of its distribution or a vanishing species (Thurman et al. 2013). However, $U$. burgersi is considered to be a habitat specialist, occurring regardless of sediment and organic matter 
content (Benetti et al. 2007). Thus, we believe that the low occurrence of this species at subarea 3-A is due to competition with other species at the area, especially $U$. thayeri, whose overlap was lower than expected by chance.

Assemblage results also showed low overlap value and a non-random pattern of species co-occurrence. This result suggests that species distributions are likely to be structured by interspecific competition (Gotelli \& Graves 1996; Gotelli \& Entsminger 2010). Although information about the impact of competition on fiddler crab distribution is still scarce, a few studies suggest that interspecific interactions may impact distribution (Frith \& Brunenmeister 1980; Robertson \& Newell 1982; Nobbs 2003). Our results indicate that these interactions should be better evaluated with further studies on Uca species distribution. In contrast, overlap for assemblages of species with setae of mixed types and highly concave curvature, as well as most species pairs, were not different from randomly generated assemblages. Thus, the observed patterns for these associations are likely to be the same with the absence of competition and environmental filtering (Gotelli \& Entsminger 2010).

Our results indicate that the morphology of mouth appendages does not determine the type of habitat that Uca species occupy. Laboratory experiments have also shown that Uca species may manipulate sediment grains of varied sizes regardless of the number of spoon-tipped setae (Colpo \& Negreiros-Fransozo 2011), indicating that the relationship between mean grain diameter and mouth appendages is not as narrow as previously thought, and our results offer field data with a niche-based approach to support this assumption. Although setal morphology has been used to explain Uca distribution (Costa \& Negreiros-Fransozo 2001; Bezerra et al. 2006; Mokhtari et al. 2015), setae may be more complex than the dual classification of spoon-tipped and plumose setae. New microscopic techniques might help in developing better guidelines to classify mouth appendage morphology (Colpo \& Negreiros-Fransozo 2013). We believe that further studies should be more cautious regarding the direct relationships of these adaptations with predicted species distribution.

Although setal type is commonly considered in Uca studies, the observation and classification of spoontipped setal curvature is relatively new, and it was suggested that they could influence fiddler crab distribution (Colpo \& Negreiros-Fransozo 2013). Our results did not support this assumption, as spoon-tipped setal curvature was not related to niche breadth or overlap. To our knowledge, this is the first evaluation of the ecological relevance of setal curvature. Thus, further studies with different species, especially at different latitudes, should be encouraged to clarify the relevance.

However, it is noteworthy that these results do not exclude the importance of mouth appendage adaptation. The number of spoon-tipped setae is related to an enhanced capacity of extracting organic matter and can be considered as an adaptation to live in organic matter depleted environments such as coarse sediment areas (Robertson \& Newell 1982; Lim 2004; Sayão-Aguiar et al. 2012). Thus, it is logical to assume that the ability to extract food from coarser grains should hypothetically expand the potential habitat occupancy of a species with spoon-tipped setae. However, U. thayeri, which possesses a predominance of plumose setae, had a higher breadth of habitat occupancy. Although these mouth appendage adaptations are important for crab feeding, our results suggest that other factors hinder the potential distribution indicated by mouth appendage morphology, whether environmental (vegetation), as suggested here, or trophic (competition), as suggested by other studies (Frith \& Brunenmeister 1980; Robertson \& Newell 1982; Nobbs 2003).

Other parameters important to fiddler crab distribution were not considered in this study and could be evaluated in future research. Because we aimed to establish the relationship between feeding appendages and distribution, considering the density of food sources at each subarea could improve our results. Descriptors of microphytobenthos (microalgal density, chlorophyll content), bacteria and protozoa could influence distribution, due to the importance of these elements as food sources to fiddler crabs (Dye \& Lasiak 1986; France 1998). The presence and density of predators may be different among areas, due to the contrasting characteristics, which may also influence species distribution. Also, although we believe that the sample from the closest body of water can be a good proxy, the most appropriate method to evaluate the influence of salinity and $\mathrm{pH}$ would be pore water samples, which could not be obtained due to the lack of pore water in the sediments of some subareas.

Our multivariate approach results corroborate the hypothesis that mean grain diameter is an important structuring factor for Uca species distribution, but niche metrics analysis rejects the hypothesis that mouth appendage similarity would result in similar habitat occupancy. The presence of vegetation influences species distribution in the area, but the responses varied among Uca species. Breadth of 
habitat occupancy was generally low, and high overlap values occurred both between species with similar and contrasting setal types. Null-models revealed no significant pattern of observed overlaps higher than expected by chance. Thus, a relationship between habitat occupancy and morphology of mouth appendages could not be established, both for setal type and curvature, which indicates that these adaptations should not be used to predict Uca species distribution. The relevance of spoon-tipped setal curvature to distribution was evaluated for the first time, but no evidence was found to identify its importance in habitat occupation.

\section{Acknowledgements}

The authors would like to thank Msc. Glauco Barreto de Oliveira Machado and Msc. João Bosco Gusmão Júnior for their help with field sampling. We would also like to thank the two anonymous reviewers for their helpful comments.

\section{Disclosure statement}

No potential conflict of interest was reported by the authors.

\section{Funding}

This work was supported by the Fundação de Amparo à Pesquisa do Estado de Sâo Paulo (FAPESP) under grant number 2010/06023-4.

\section{References}

Anderson MJ. 2008. Animal-sediment relationships re-visited: characterizing species distribution along an environmental gradient using canonical analysis and quantile regression splines. Journal of Experimental Marine Biology and Ecology 366:16-27. doi:10.1016/j.jembe.2008.07.006

Benetti AS, Negreiros-Fransozo ML, Costa TM. 2007. Population and reproductive biology of the crab Uca burgersi (Crustacea: Ocypodidae) in three subtropical mangrove forests. Revista de Biologia Tropical 55:55-70.

Bertness MD, Miller T. 1984. The distribution and dynamics of Uca pugnax (Smith) burrows in a New England salt marsh. Journal of Experimental Marine Biology and Ecology 83:211-37. doi:10.1016/S0022-0981(84)80002-7

Bezerra LEA, Dias CB, Santana GX, Matthews-Cascon H. 2006. Spatial distribution of fiddler crabs (genus Uca) in a tropical mangrove of northeast Brazil. Scientia Marina 70:759-66. doi:10.3989/scimar.2006.70n4759

Blanchet GF, Legendre P, Borcard D. 2008. Forward selection of explanatory variables. Ecology 89:2623-32. doi:10.1890/ 07-0986.1

Brenchley GA. 1982. Mechanisms of spatial competition in marine soft-bottom communities. Journal of Experimental Marine Biology and Ecology 60:17-33. doi:10.1016/0022-0981(81)90177-5
Cesar II, Armendáriz LC, Becerra RV. 2005. Bioecology of the fiddler crab Uca uruguayensis and the burrowing crab Chasmagnathus granulatus (Decapoda, Brachyura) in the Refugio de Vida Silvestre Bahía Samborombón, Argentina. Hydrobiologia 545:237-48. doi:10.1007/ s10750-005-3317-0

Christy JH, Backwell PYR, Goshima S, Kreuter T. 2002. Sexual selection for structure building by courting male fiddler crabs: an experimental study of behavioral mechanisms. Behavioral Ecology 13:366-74. doi:10.1093/beheco/13.3. 366

Colpo KD, Negreiros-Fransozo ML. 2011. Sediment particle selection during feeding by four species of Uca (Brachyura, Ocypodidae). Crustaceana 84:721-34. doi:10. 1163/001121611X577891

Colpo KD, Negreiros-Fransozo ML. 2013. Morphological diversity of setae on the second maxilliped of fiddler crabs (Decapoda: Ocypodidae) from the southwestern Atlantic coast. Invertebrate Biology 132:38-45. doi:10.1111/ivb. 12004

Costa TM, Negreiros-Fransozo ML. 2001. Morphological adaptation of the 2 nd maxilliped in semiterrestrial crabs of the genus Uca from a subtropical Brazilian mangrove. Nauplius 9:123-31.

Crane J. 1975. Fiddler Crabs of the World. Princeton, NJ: Princeton University Press. 737 pages.

Currin CA, Newell SY, Paerl HW. 1995. The role of standing dead Spartina alterniflora and benthic microalgae in salt marsh food webs: considerations based on multiple stable isotope analysis. Marine Ecology Progress Series 121:99-116. doi:10.3354/meps121099

Dye AH, Lasiak TA. 1986. Microbenthos, meiobenthos and fiddler crabs: trophic interactions in a tropical mangrove sediment. Marine Ecology Progress Series 32:259-64. doi:10.3354/meps032259

France R. 1998. Estimating the assimilation of mangrove detritus by fiddler crabs in Laguna Joyuda, Puerto Rico, using dual stable isotopes. Journal of Tropical Ecology 14:413-25. doi:10.1017/S0266467498000315

Frith DW, Brunenmeister S. 1980. Ecological and population studies of fiddler crabs (Ocypodidae, genus Uca) on a mangrove shore at Phuket Island, western Peninsular Thailand. Crustaceana 39:157-84. doi:10.1163/156854080X00067

Gotelli NJ, Entsminger GL. 2010. EcoSim: Null Modeling Software for Ecology Version 7. Jericho, VT: Acquired Intelligence Inc. \& Kesey-Bear. http://garyentsminger. com/ecosim/index.htm. Computer program.

Gotelli NJ, Graves GR. 1996. Null Models in Ecology. Washington: Smithsonian Institution Press. 368 pages.

Gray JS. 1974. Animal-sediment relationships. Oceanography and Marine Biology: An Annual Review 12:223-61.

Gusmão-Junior JBL, Machado GBO, Costa TM. 2012. Burrows with chimneys of the fiddler crab Uca thayeri: construction, occurrence and function. Zoological Studies 51:598-605.

Hyland J, Balthis L, Karakassis I, Magni P, Petrov A, Shine J, et al. 2005. Organic carbon content of sediments as an indicator of stress in the marine benthos. Marine Ecology Progress Series 295:91-103. doi:10.3354/meps295091

James MC, McCulloch CE. 1990. Multivariate analysis in ecology and systematics: panacea or Pandora's box? Annual Review of Ecology and Systematics 21:129-66. doi:10.1146/annurev.es.21.110190.001021 
Kon K, Kurokura H, Tognunui P. 2009. Do mangrove roots structures function to shelter benthic macrofauna from predators? Journal of Experimental Marine Biology and Ecology 370:1-8. doi:10.1016/j.jembe.2008.11.001

Krebs CJ. 1989. Ecological Methodology. New York: Harper \& Hall. 745 pages

Kristensen E. 2008. Mangrove crabs as ecosystem engineers; with emphasis on sediment processes. Journal of Sea Research 59:30-43. doi:10.1016/j.seares.2007.05.004

Legendre P, Gallagher RD. 2001. Ecologically meaningful transformations for ordination of species data. Oecologia 129:271-80. doi:10.1007/s004420100716

Lim SSL. 2004. A comparative study of some mouthpart adaptations of Uca annulipes (H. Milne Edwards, 1837) and U. vocans (Linnaeus, 1758) (Brachyura, Ocypodidae) in relation to their habitats. Crustaceana 77:1245-51. doi:10. $1163 / 1568540043166128$

Lim SSL, Diong CH. 2003. Burrow-morphological characters of the fiddler crab, Uca annulipes ( $\mathrm{H}$. Milne Edwards, 1837) and ecological correlates in a lagoonal beach on Pulau Hantu, Singapore. Crustaceana 76:1055-69. doi:10.1163/ 156854003322753411

Lim SSL, Kalpana S. 2011. Maxilliped-setation adaptations to habitat and sexual dimorphism of feeding claws in Uca perplexa and U. vomeris. Journal of Crustacean Biology 31:40612. doi:10.1651/10-3416.1

Lim SSL, Rosiah A. 2007. Influence of pneumatophores on the burrow morphology of Uca annulipes (H Milne Edwards, 1837) (Brachyura, Ocypodidae) in the field and simulated mangrove micro-habitats. Crustaceana 80:1327-38. doi:10.1163/156854007782605529

Machado GB, Gusmão-Júnior JB, Costa TM. 2013. Burrow morphology of Uca uruguayensis and Uca leptodactylus (Decapoda: Ocypodidae) from a subtropical mangrove forest in the Western Atlantic. Integrative Zoology 8:30714. doi:10.1111/j.1749-4877.2012.00297.x

McCammon RB. 1962. Efficiencies of percentile measures for describing the mean size and sorting of sedimentary particles. Journal of Geology 70:453-65. doi:10.1086/626836

Miller DC. 1961. The feeding mechanism of fiddler crabs, with ecological considerations of feeding adaptations. Zoologica 46:89-100.

Mokhtari M, Ghaffar MA, Usup G, Cob ZC. 2015. Determination of key environmental factors responsible for distribution patterns of fiddler crabs in a tropical mangrove ecosystem. PLoS One 10(1):e117467. 17 pages. doi:10.1371/journal.pone.0117467

Morrisey DJ, DeWitt TH, Roper DS, Williamson RB. 1999. Variation in the depth and morphology of burrows of the mud crab Helice crassa among different types of intertidal sediment in New Zealand. Marine Ecology Progress Series 182:231-42. doi:10.3354/meps 182231

Nobbs M. 2003. Effects of vegetation differ among three species of fiddler crabs (Uca spp.). Journal of Experimental Marine Biology and Ecology 284:41-50. doi:10.1016/S0022-0981(02)00488-4

Ono Y. 1965. On the ecological distribution of ocypodid crabs in the estuary. Memoirs of the Faculty of Science 4:1-60.
Pianka ER. 1973. The structure of lizard communities. Annual Review of Ecology and Systematics 4:53-74. doi:10.1146/ annurev.es.04.110173.000413

Quinn G, Keough M. 2002. Experimental Design and Data Analysis for Biologists. Cambridge, UK: Cambridge University Press. 553 pages.

Quresh NA, Saher NU. 2012. Burrow morphology of three species of fiddler crab (Uca) along the coast of Pakistan. Belgian Journal of Zoology 142:114-26.

Ribeiro PD, Iribarne OO. 2011. Coupling between microphytobenthic biomass and fiddler crab feeding. Journal of Experimental Marine Biology and Ecology 407:147-54. doi:10.1016/j.jembe.2011.05.030

Robertson JR, Newell SY. 1982. Experimental studies of particle ingestion by the sand fiddler crab Uca pugilator. Journal of Experimental Marine Biology and Ecology 59:1-21. doi:10.1016/0022-0981(82)90102-2

Salmon M. 1987. On the reproductive behavior of the fiddler crab Uca thayeri, with comparisons to $U$. pugilator and $U$. vocans: evidence for behavioral convergence. Journal of Crustacean Biology 7:25-44. doi:10.2307/1548623

Sayão-Aguiar B, Pinheiro MAA, Colpo KD. 2012. Sediment bioturbation potential of Uca rapax and Uca uruguayensis as a result of their feeding activity. Journal of Crustacean Biology 32:223-29. doi:10.1163/193724011X615451

Swihart RK, Gehring TM, Kolozsvary MB, Nupp TE. 2003. Response of 'resistant' vertebrates to habitat loss and fragmentation: the importance of niche breadth and range boundaries. Diversity and Distributions 9:1-18. doi:10. 1046/j.1472-4642.2003.00158.x

Tenore KR. 1983. Organic nitrogen and caloric content of detritus III. Effect on growth of a deposit-feeding polychate, Capitella capitata. Estuarine, Coastal and Shelf Science 17:733-42. doi:10.1016/0272-7714(83)90039-2

Thrush SF, Hewitt JE, Herman PMJ, Ysebaert T. 2005. Multi-scale analysis of species-environment relationships. Marine Ecology Progress Series 302:13-26. doi:10.3354/meps302013

Thurman CL. 1987. Fiddler crabs (genus Uca) of Eastern Mexico (Decapoda, Brachyura, Ocypodidae). Crustaceana 53:94-105. doi:10.1163/156854087X00664

Thurman CL, Faria SC, McNamara JC. 2013. The distribution of fiddler crabs (Uca) along the coast of Brazil: implications for biogeography of the western Atlantic Ocean. Marine Biodiversity Records 6:e1. 21 pages. doi:10.1017/ S1755267212000942

Vermeiren P, Sheaves M. 2014. Predicting habitat associations of five intertidal crab species among estuaries. Estuarine, Coastal and Shelf Science 149:133-42. doi:10.1016/j.ecss. 2014.08.008

Wentworth CK. 1922. A scale of grade and class terms for clastic sediments. Journal of Geology 30:377-92. doi:10. 1086/622910

Whitcraft CR, Levin LA. 2007. Regulation of benthic algae and animal communities by salt marsh plants: impacts of shading. Ecology 88:904-17. doi:10.1890/05-2074

Yamaguchi T, Ogata R. 2000. Studies of the first and second maxillipeds of the fiddler crab Uca lactea. Crustacean Research 29:133-42. 